УДК: $371(477.84)$

https://doi.org/10.33296/2707-0255-10(19)-06

https://orcid.org/0000-0003-4207-0624

\title{
БОДНАР ОКСАНА,
}

Доктор педагогічних наук, доцент

професор кафедри педагогіки та

менеджменту освіти

Тернопільський національний

педагогічний університет імені

Володимира Гнатюка

м.Тернопіль, Україна

\section{ПІДГОТОВКА КЕРІВНИКА ЗАКЛАДУ ОСВІТИ ДО АДАПТИВНОГО УПРАВЛІННЯ В УМОВАХ МАГІСТРАТУРИ: КОНЦЕПТУАЛЬНІ ШТРИХИ МОДЕРНІЗАЦЇ̈}

Анотація. У статті розглянуто проблеми, пов'язані 3 підготовкою керівника закладу освіти до адаптивного управління в умовах магістратури. Зокрема наведено теоретичні здобутки щодо підготовки фахівців з управління у науці. Наголошено на тому, що можливості використання адаптивного підходу та механізмів вдосконалення підготовки спеціалістів 3 управління освітою в педагогічній науці не вичерпані. Розкрито концептуальні ідеї адаптивного управління у вітчизняному та зарубіжному менеджменті та окреслено значення такого управління для підвищення якості підготовки керівників освіти. Зазначено, які теми варто вивчати з адаптивного управління для вдосконалення підготовки керівника закладу освіти в умовах магістратури. Запропоновано концепцію Кайдзена 3 японського менеджменту для модернізації підготовки фахівців зі спеціальності 073 Менеджмент в умовах магістратури. Окреслено нові завдання такої підготовки. Розкрито принципи, які внесуть нові елементи у підготовку фахівців та показано модель компетентності майбутніх спеціалістів, яка може бути використана в освітньо-науковій програмі. Модель компетентності майбутнього керівника освіти 3 проблем адаптивного управління розроблена за дескрипторами відповідно до специфіки адаптивного управління.

Подальших досліджень потребує дослідження проблем розробки критерії оцінювання компетентності магістрів щодо використання механізмів адаптивного управління, обгрунтування моделі управлінської практики в дистанційному режимі та розробки тестових завдань для перевірки відповідної компетентності.

Ключові слова: адаптивне управління, підготовка керівників, магістратура, модернізація, освітньо-наукова програма, концепція Кайдзена, модель компетентності. 
Актуальність дослідження i постановка проблеми. Зростаюча конкурентність між організаціями, перспективи цифровізації, великий розрив між структурою та змістом компетентності молодого та досвідченого поколінь - такі виклики зумовлюють підвищені вимоги до керівників закладів та установ освіти. Динаміка розвитку освітнього середовища породжує великі і малі проблеми, які доводиться вирішувати керівникам повсякденно, тому споживачі освітніх послуг вимагають від керівників негайних і гнучких рішень. Відтак зауважується активне проникнення адаптивних процесів у всі сфери суспільного життя. Адаптивність стала - головною характеристикою професіонала. Сьогодні керівник закладу освіти - це передусім людина 3 гнучким мисленням та сформованою компетентністю, складовою якої $\epsilon$ здатність до застосування механізмів адаптивного управління. Оскільки керівника у нинішніх умовах готують заклади вищої освіти, постає потреба пошуку інструментів модернізації такої підготовки майбутніх керівників освіти в умовах навчання в магістратурі відповідно до цивілізаційних викликів та розвитку менеджменту.

Мета статті полягає в дослідженні і аналізі теоретичних здобутків адаптивного управління як ефективного інструменту швидкого та адекватного розв'язання проблем у системі освіти та пошуку нових концептуальних шляхів модернізації підготовки керівників освіти у рамках магістратури.

Аналіз попередніх досліджень і публікацій. Діяльність керівника складна і відповідальна, але у директора школи - особлива місія. Він покликаний поєднувати в одній особі вчителя, методиста, інспектора, господарника, організатора навчально-виховного процесу, чуйного і уважного наставника дитячого колективу, лідера для колег-педагогів [8, с.15].

Підготовка керівника освіти в умовах закладу вищої освіти представлена роботами Г.В. Сльникової [3], В.І. Маслов [6], Т.М. Сорочан [10], Т.О. Дмитренко, С.В. Копилової [2], А.В. Роміна [11], А.І. Чміля [9], О.В. 
Лебідь [5],С.Г. Немченко [7] та багато інших. У роботах цих авторів розроблені основні концептуальні ідеї формальної та неформальної освіти, напрями, принципи, закономірності, методи і форми підготовки керівників. Окремий напрям досліджень присвячений розробці моделі компетентності керівників освіти: управлінської (В.І. Маслов, Л.І. Даниленко, Г.В. Єльникова); економічної (Т.І. Бурлаєнко); правової (В.В. Олійник); самоосвітньої (Т.Б. Волобуєва). Крім цього, досліджується підготовка керівника до адаптивного управління (Г.В. Сльникова); рефлексивного управління (С.Г. Немченко); стратегічного управління (О.І. Лебідь); проектно-цільового (Г.А. Дмитренко).

Переваги адаптивного управління знайшли своє відображення у роботах Г.В. Сльникової та іiі учнів та таких послідовників, як: Т.А. Борова, Л.І. Фесік, Г.А. Полякова, І.В. Назарук, О.О. Почуєва, О.А. Сременко, В.М. Швидун та інші.

Виділення невирішених раніше частин загальної проблеми, яким присвячусться означена стаття. Незважаючи на наявність робіт, які досліджують важливість адаптивного управління у підготовці керівників закладів освіти, не до кінця розкрито механізми модернізації такої підготовки відповідно до запитів управлінської практики та напрямів розвитку менеджменту.

Викладення основного матеріалу. Сучасні дослідники стверджують, що за останнє десятиріччя доводить, що можливості використання адаптивного підходу в педагогічній науці не вичерпані [2].

Керівники закладів освіти відіграють ключову роль у впливі на клімат, ставлення та репутацію своїх шкіл. Вони є наріжним каменем, на якому навчальні спільноти функціонують та ростуть [18].

Сьогодні вказують «на неадекватність деяких «передових» моделей професійної підготовки керівників» не тільки в Україні, але й в дальньому зарубіжжі. Автори підкреслюють проблему, яка є типовою для усіх закладів вищої освіти. Ця проблема полягає в тому, що коли студенти отримують 
теоретичні знання 3 управління та менеджменту, вони виявляються непридатними для того, щоб брати участь у прийнятті рішень і плануванні розвитку у всій школі безпосередньо під час виконання своїх обов’язків керівника [15].

Дослідники зарубіжного менеджменту вказують на те, що адаптивне управління дає змогу індентифікувати невизначеності, а потім встановлює методологію для перевірки гіпотез щодо цих невизначеностей, оскільки адаптивне управління є інструментом не тільки для зміни системи, але і як інструмент для вивчення системи [14].

Процеси адаптивного управління можуть бути як активними, так i пасивними; активне адаптивне управління передбачає тестування декількох варіантів одночасно для того, щоб визначити найкращу стратегію, тоді як пасивне адаптивне управління вимагає вибору та реалізації одного варіанту та моніторингу, щоб визначити, чи потрібні коригування [19].

Адаптивне управління не $є$ самоціллю, а засобом прийняття більш ефективних рішень та посилення вигод шляхом моніторингу впливу управлінських практик на досягнення бажаного результату. Адаптивне управління можна охарактеризувати як цикл ітеративних дій, де кожен крок базується на навчальному досвіді попередніх кроків, оскільки калібрування цілей та завдань проводиться за допомогою процесу зворотного зв’язку, який визначається шляхом оцінки та аналізу даних моніторингу. Кожен крок періодично калібрується, щоб гарантувати, що відповідна інформація подає наступний рівень. Циклічність процесу дуже важлива для перевірки результатів окремих етапів [17].

На думку Г.В. Сльникової, адаптивне управління - процес взаємовпливу, що викликає взаємопристосування поведінки суб'єктів діяльності на діа(полі)логічній основі, що забезпечується спільним визначенням реалістичної мети 3 наступним поєднанням зусиль і самоспрямуванням дій на їі досягнення адаптивне управління стає гнучким і динамічним, враховуючим потреби не 
тільки суб’єкта, а й об’єкта управлінської діяльності, що інтегрується в спільній меті [4]. Адаптивне керівництво розглядається як здатність керівника обирати й поєднувати різні стилі управління залежно від ситуації. При цьому підвищення адаптивності керівництва досягається за рахунок переформування творчих груп, перепроектування завдань або модифікації посадових повноважень [12].

Як зауважують зарубіжні автори, процес адаптивного управління, як правило, має три фази: оцінку, моделювання та експерименти з управління [16]. Тому підготовка керівника закладу освіти в умовах магістратури, з нашої точки зору, потребує вивчення таких тем, як «Структура та зміст оцінювання як функції управління», «Організація моніторингу у закладі освіти», «Вимірювання в освітньому процесі», «Теорія тесту», «Застосування технології моделювання в управлінській діяльності керівника». Ці теми вивчаються у курсах «Менеджмент організацій», «Управління трудовими ресурсами», «Аудит та оцінювання управлінської діяльності», «Самоменеджмент», «Сучасні технології управління закладом освіти».

Важливість модернізації підготовки керівників освіти обгрунтовує А.В.Ромін, вказуючи на те, що неможливо надати послуги в повному обсязі заздалегідь і складувати їх як матеріальний товар в очікуванні підвищення попиту; з часом людина забуває отриману інформацію, знання, а також відбувається також старіння знань [11].

Головна концептуальна ідея, яка допоможе модернізувати підготовку керівників освіти - це застосувати японську концепцію Кайдзена, яка полягає у наступному: розглядати проблеми як можливості, а не щось, що треба прикривати; ліквідація даремно потраченого часу, енергії, ресурсів (очікування наради, лекції, інформації, підготовка довідок, які ніде не використовуються тощо); не можна чекати якісних результатів, якщо ми не думаємо про якісний процес (який складається з дисципліни, управління часом, розвитку навичок, участі, морального духу та спілкування); не можна жертвувати якістю ради кількості; для операційних змін не потрібно збільшувати ресурсів [13]. Ця 
концепція може стати стартовою у модернізації підготовки керівників закладів освіти. Тобто, якщо ми хочемо вдосконалити форму підготовки фахівців 3 управління закладом освіти, не треба шукати додаткових ресурсів. Можна, на нашу думку, використовувати для окремих лекцій управлінців-практиків, які мають досвід, наприклад, у розробці програми розвитку.

Тому пропонуємо включити такі завдання у підготовку керівників до адаптивного управління закладами освіти:

- пошук механізмів кореляції між теоретичними знаннями та необхідними компетентностями застосування знань з адаптивного управління на практиці;

- включення необхідних компетентностей адаптивного управління у різні навчальні дисципліни;

- залучення керівників практиків для презентації досвіду використання адаптивних механізмів для планування та розвитку закладу;

- забезпечити інтеграцію багаторівневої підготовки до адаптивного управління: самоосвіта - дистанційна освіта - навчання оф-лайн - управлінська практика - презентація магістерського дослідження - використання адаптивного управління у професії;

- диверсифікація курсів за вибором, що орієнтовані на формування гнучкості у ідентифікації проблем та прийнятті рішень;

Для реалізації названих завдань у підготовці керівників варто дотримуватись таких принципів:

реалізацї адаптивного підходу до підготовки керівників освіти, що передбачає дослідження та використання адаптивних систем процесі навчання; - системності орієнтує на повне використання змістових компонентів адаптивного управління;

аналогї̈ ситуацій забезпечує повторне застосування методів і форм підготовки керівників з опорою на адаптивні механізми; 
практичної логіки для аналізу невизначеності в освітньому середовищі, що провокує збурення та перешкоди у прийнятті рішень щодо використання інновацій;

- стратегії комбінування для одночасного використання формалізованих методів, наукових підходів, інтелекту та творчості при формуванні управлінської компетентності;

- $\quad$ Life Long Learning - вчити усіх усьому в будь-якому віці, тобто навчати у магістратурі теорії і практики адаптивного управління студентів будь-якого віку і бажано використовувати максимальну кількість навчальних дисциплін.

Для модернізації підготовки керівників освіти в освітню програму варто внести програмні компетентності, пов'язані 3 концепцією адаптивного управління (табл. 1).

Таблиця 1

\section{Структура компетентності майбутнього керівника освіти 3}

\section{адаптивного управління}

\begin{tabular}{|c|c|}
\hline Дескриптори & Сутність компетентності \\
\hline Знання & 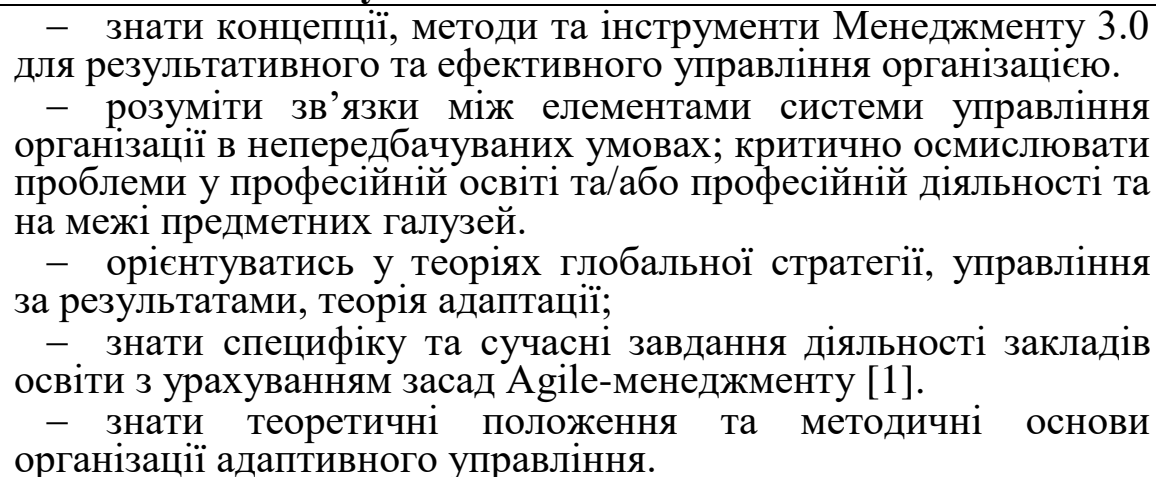 \\
\hline У МіннЯ & 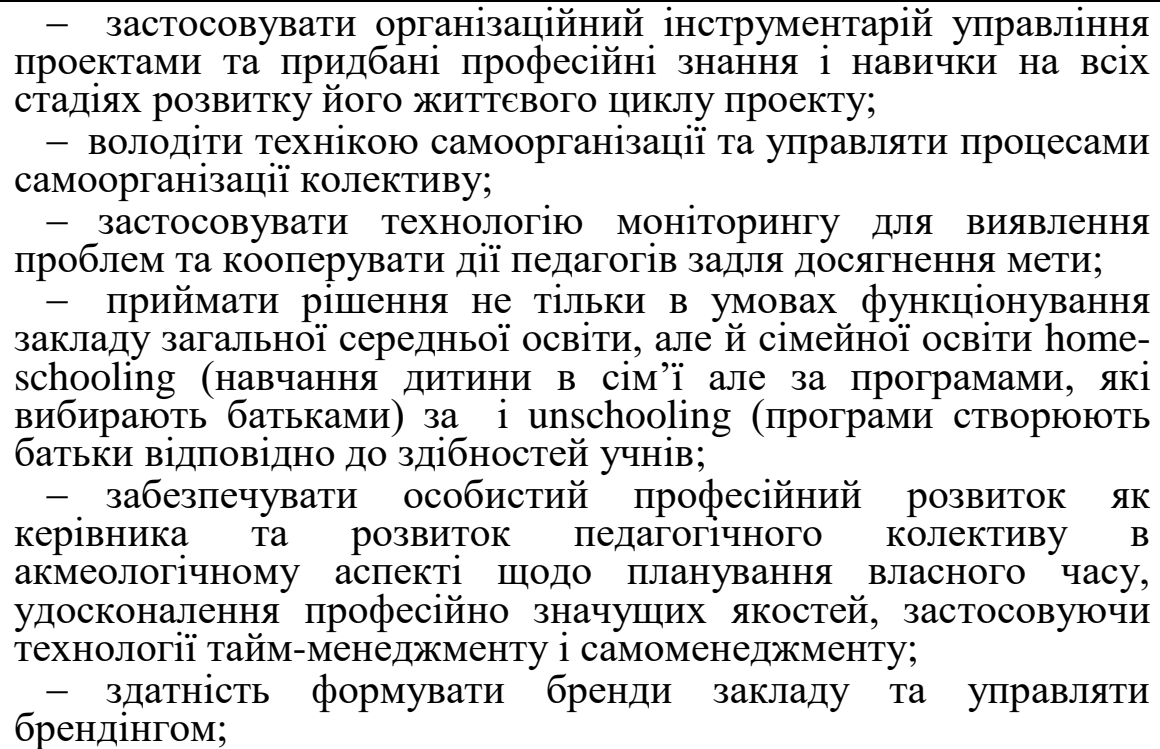 \\
\hline
\end{tabular}

(C) Українська інженерно-педагогічна академія

(c) ГО «Школа адаптивного управління сочіально-педагогічними системами»

(C) Боднар 0. 
Продовження табл. 1

\begin{tabular}{|c|c|}
\hline Комунікація & $\begin{array}{l}\text { - аналізувати комунікативну ситуацію і використовувати у } \\
\text { професійній діяльності українську та іноземну мови, вміти } \\
\text { виражати чітко і грамотно свої знання і думки у різних формах } \\
\text { та стилях мовлення під час спілкування; } \\
\text { - організовувати та здійснювати ефективні комунікації } \\
\text { всередині колективу, } 3 \text { представниками різних професійних } \\
\text { груп, } 3 \text { органами місцевого самоврядування, батьківською } \\
\text { спільнотою та в міжнародному контексті; } \\
\text { - демонструвати вміння взаємодіяти з людьми та впливати } \\
\text { на їх поведінку, підтримувати і виявляти увагу до іншої думки, } \\
\text { працювати у команді для вирішення професійних задач; }\end{array}$ \\
\hline $\begin{array}{l}\text { Автономія та } \\
\text { відповідальність }\end{array}$ & 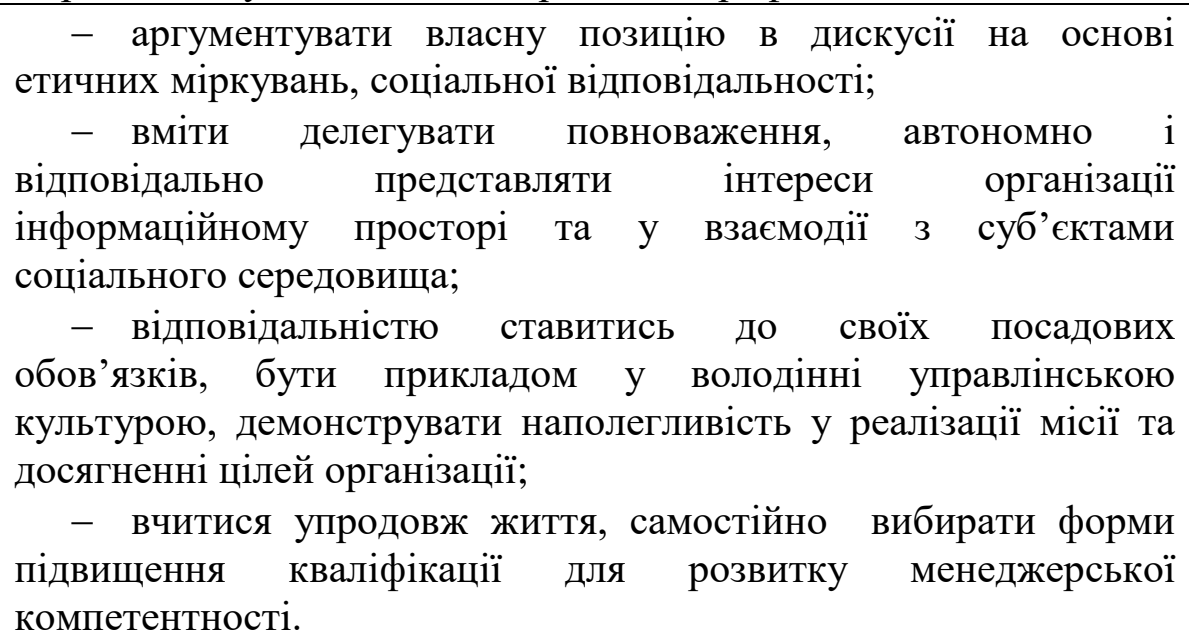 \\
\hline
\end{tabular}

Висновки. Отже, незважаючи на те, що система підготовки майбутніх керівників освіти в університетах налагоджена, іiі модернізація - завдання кожного університету зокрема. Для підвищення якості підготовки спеціалістів 3 управління в умовах магістратури, необхідно оновлювати завдання відповідно до запитів ринку праці; змінювати принципи підготовки; шукати нові концепції в менеджменті, деталізувати компетентності в дескрипторах і програмні результати освітньої програми; розробляти завдання для управлінської практики з проблем адаптивного управління.

Подальших досліджень потребує дослідження проблем розробки критерії оцінювання компетентності магістрів щодо використання механізмів адаптивного управління, обгрунтування моделі управлінської практики в

\footnotetext{
(C) Українська інженерно-педагогічна академія

(c) ГО «Школа адаптивного управління соціально-педагогічними системами»

(C) Боднар 0.
} 
дистанційному режимі та розробки тестових завдань для перевірки відповідної компетентності.

\section{СПИСОК ВИКОРИСТАНИХ ДЖЕРЕЛ}

1. Аппело Ю. Менеджмент 3.0. Agile-менеджмент. Лідерство та управління команди. Харків: Вид-во «Ранок»: Фабула, 2019. 432 с.

2. Дмитренко Т.О., Копилова С.В. Концептуальні засади адаптивної системи професійної підготовки магістрів соціальної роботи. Педагогіка формування творчої особистості у вищій $i$ загальноосвітній школах: зб. наук.пр./ редкол.: Т.І.Сущенко (голов.ред.) та ін. Запоріжжя: КПУ, 2015. Вип.43 (96). С.501- 508.

3. Сльникова Г.В. Підготовка керівників шкіл до адаптивного управління. Підготовка керівника середнього закладу освіти: Навчальний посібник. За ред. Л.І. Даниленко. К.: Міленіум, 2004. С. 133-141.

4. Сльникова Г.В. Наукові основи адаптивного управління закладами та установами загальної середньої освіти : Дис. ... д-ра пед. наук: 13.00.01. К., $2005.641 \mathrm{c}$.

5. Лебідь О. Теоретичні аспекти підготовки майбутнього керівника загальноосвітнього навчального закладу до стратегічного управління в умовах магістратури.

URL: https://www.researchgate.net/publication/334233744_Teoreticni_aspekti_pidgotovki_ majbutnogo_kerivnika_(дата звернення 21.04.2020).

6. Маслов В.І. Наукові засади визначення змісту підвищення кваліфікації та підготовки керівників загальноосвітніх навчальних закладів. Післядипломна освіта в Україні. 2002. № 2. С. 63-66.

7. Немченко С.Г. Теоретичні і методичні засади підготовки керівника загальноосвітнього навчального закладу до рефлексивного управління у педагогічних університетах : монографія. Бердянськ : Видавець Ткачук О.В., 2017. URL: http://bdpu.org:8080/bitstream/123456789/1551/1/Nemchenko\% (дата звернення 06.05.2020).

8. Пшенична Л.В. Керівник навчального закладу: навч. посіб. Суми: Вид-во СумДПУ імені А. С. Макаренка, 2016. 520 с.

9. Підготовка керівника навчального закладу до управлінської діяльності в ринкових умовах: навч. посіб. / А.І. Чміль, В.І. Маслов, Г.А. Дмитренко, Г.В.Сльникова, Г.В.Федоров. / за ред. А. І. Чміля. К. : Логос, 2006. 126 с.

10. Сорочан Т. М. Підготовка керівників шкіл до управлінської діяльності: теорія та практика : монографія Луганськ : Знання, 2005. 384 с.

11. Ромін А. В. Механізми державного управління. Актуальні проблеми державного управління : зб. наук. пр. Х. : Вид-во ХарРІ НАДУ “Магістр”, 2014. - № 2 (46). 320 c

12. Фесік Л.І.. Адаптивне управління: еволюція поняття та сутнісна характеристика. Теорія та методика управління освітою, випуск № 5, грудень 
2010 p. URL: http://tme.umo.edu.ua/docs/5/11fescec.pdf. Загол. 3 екрану. (дата звернення 14.02.2020).

13. Agadoni Laura. What Is the Kaizen Concept? URL: https://yourbusiness.azcentral.com/demings-principles-leadership-10832.html (дата звернення 06.05.2020).

14. Adaptive Management. [Назва 3 екрану]. URL: https://www.resalliance.org/adaptive-mgmt (дата звернення 14.03.2020).

15. Brown, M., Boyle, B. and Boyle, T. (2002). Professional development and management training needs for heads of department in UK secondary schools. Journal of Educational Administration. Vol. 40 No. 1, pp.31-43. URL: https://www.emerald.com/insight/content/doi/10.1108/09578230210415634/full/html (дата звернення 23.06.2020).

16. Garry D. Peterson, in Ecological Paradigms Lost, Routes of Theory Change. Theoretical Ecology Series 2005/ URL: https://www.sciencedirect.com/science/article/pii/B9780120884599500182 (дата звернення 23.06.2020).

17. Framework for Assessment and Monitoring of Biodiversity. Encyclopedia of Biodiversity (Second Edition) 2013 https://www.sciencedirect.com/topics/earth-and-planetary-sciences/adaptivemanagement (дата звернення 06.05.2020).

18. Joseph Lathan, PhD. 10 Traits of Successful School Leaders https://onlinedegrees.sandiego.edu/effective-educational-leadership/ (дата звернення 16.07.2020).

19. Kingsford, R.T., Roux, D.J., McLoughlin, C.A., Conallin, J., Norris, V. Intermittent Rivers and Ephemeral Streams. Ecology and Management 2014 https://www.sciencedirect.com/topics/earth-and-planetary-sciences/adaptive-(дата звернення 10.04.2020).

\section{References}

1. Appelo Yu. Menedzhment 3.0. Agile-menedzhment. Liderstvo ta upravlinnya komandy`. Xarkiv: Vy`d-vo «Ranok»: Fabula, 2019. $432 \mathrm{~s}$.

2. Dmytrenko T.O., Kopylova S.V. Kontseptualni zasady adaptyvnoi systemy profesiinoi pidhotovky mahistriv sotsialnoi roboty. Pedahohika formuvannia tvorchoi osobystosti u vyshchii i zahalnoosvitnii shkolakh: zb. nauk.pr./ redkol.: T.I.Sushchenko (holov.red.) ta in. Zaporizhzhia: KPU, 2015. Vyp.43 (96). S.501508.

3. Ielnykova H.V. Pidhotovka kerivnykiv shkil do adaptyvnoho upravlinnia. // Pidhotovka kerivnyka serednoho zakladu osvity: Navchalnyi posibnyk. Za red. L.I.Danylenko. K.: Milenium, 2004. S. 133-141.

4. Сльникова Г.В. Наукові основи адаптивного управління закладами та установами загальної середньої освіти : Дис. ... д-ра пед. наук: 13.00.01. К., 2005. $641 \mathrm{c}$. 
5. Lebid O. Teoretychni aspekty pidhotovky maibutnoho kerivnyka zahalnoosvitnoho navchalnoho zakladu do stratehichnoho upravlinnia $\mathrm{v}$ umovakh mahistratury.

URL: https://www.researchgate.net/publication/334233744_Teoreticni_aspekti_pidgotovki _majbutnogo_kerivnika_(data zvernennia 21.04.2020).

6. Maslov V.I. Naukovi zasady vyznachennia zmistu pidvyshchennia kvalifikatsii ta pidhotovky kerivnykiv zahalnoosvitnikh navchalnykh zakladiv. Pisliadyplomna osvita v Ukraini. 2002. № 2. S. 63-66.

7. Nemchenko S.H. Teoretychni i metodychni zasady pidhotovky kerivnyka zahalnoosvitnoho navchalnoho zakladu do refleksyvnoho upravlinnia $u$ pedahohichnykh universytetakh : monohrafiia. Berdiansk : Vydavets Tkachuk O.V., 2017. URL: http://bdpu.org:8080/bitstream/123456789/1551/1/Nemchenko\% (data zvernennia 06.05.2020).

8. Pshenychna L.V. Kerivnyk navchalnoho zakladu: navch. posib. Sumy: Vyd-vo SumDPU imeni A. S. Makarenka, 2016. $520 \mathrm{~s}$.

9. Pidhotovka kerivnyka navchalnoho zakladu do upravlinskoi diialnosti v rynkovykh umovakh: navch. posib. / A.I. Chmil, V.I. Maslov, H.A. Dmytrenko, H.V.Ielnykova, H.V.Fedorov. / za red. A. I. Chmilia. K. : Lohos, 2006. 126 s.

10. Sorochan T. M. Pidhotovka kerivnykiv shkil do upravlinskoi diialnosti: teoriia ta praktyka : monohrafiia Luhansk : Znannia, 2005. $384 \mathrm{~s}$.

11. Romin A. V. Mekhanizmy derzhavnoho upravlinnia. Aktualni problemy derzhavnoho upravlinnia : zb. nauk. pr. Kh. : Vyd-vo: KharRI NADU "Mahistr", 2014. - № 2 (46). 320 s.

12. Fesik L.I. Adaptyvne upravlinnia: evoliutsiia poniattia ta sutnisna kharakterystyka. Teoriia ta metodyka upravlinnia osvitoiu. Vypusk № 5, hruden 2010 r. URL: http://tme.umo.edu.ua/docs/5/11fescec.pdf. Zahol. z ekranu. (data zvernennia 14.02.2020).

13. Agadoni Laura. What Is the Kaizen Concept? URL: https://yourbusiness.azcentral.com/demings-principles-leadership-10832.html (дата звернення 06.05.2020).

14. Adaptive Management. [Назва 3 екрану]. URL: https://www.resalliance.org/adaptive-mgmt (дата доступу 14.03.2020).

15. Brown, M., Boyle, B. and Boyle, T. (2002), Professional development and management training needs for heads of department in UK secondary schools. Journal of Educational Administration. Vol. 40 No. 1, pp. 31-43. URL: https://www.emerald.com/insight/content/doi/10.1108/09578230210415634/full/html

16. Garry D. Peterson, in Ecological Paradigms Lost, Routes of Theory Change. Theoretical Ecology Series 2005/ URL: https://www.sciencedirect.com/science/article/pii/B9780120884599500182 _дата звернення 23.06.2020).

17. Dallmeier Francisco, Szaro, Robert C., Alonso, Alfonso, Comiskey, James and Henderson Ann (2013). Framework for Assessment and Monitoring of Biodiversity. In: Levin S.A. (ed.) Encyclopedia of Biodiversity, second edition, 
Volume 3, pp. 545-559. Waltham, MA: Academic Press. URL:https://www.sciencedirect.com/topics/earth-and-planetary-sciences/adaptivemanagement (дата звернення 06.05.2020).

18. Joseph Lathan, PhD. 10 Traits of Successful School Leaders https://onlinedegrees.sandiego.edu/effective-educational-leadership/ (дата звернення 16.07.2020).

19. Kingsford, R.T., Roux, D.J., McLoughlin, C.A., Conallin, J., Norris, V. Intermittent Rivers and Ephemeral Streams. Ecology and Management 2014 https://www.sciencedirect.com/topics/earth-and-planetary-sciences/adaptive-(data zvernennia 10.04.2020).

\section{БОДНАР ОКСАНА,} доктор педагогических наук, доцент профессор кафедры педагогики и менеджмента образования Тернопольский национальный педагогический университет имени Владимира Гнатюка Тернополь, Украина

\section{ПОДГОТОВКА РУКОВОДИТЕЛЯ УЧРЕЖДЕНИЯ ОБРАЗОВАНИЯ К АДАПТИВНОМУ УПРАВЛЕНИЮ В УСЛОВИЯХ МАГИСТРАТУРЫ: КОНЦЕПТУАЛЬНЫЕ ШТРИХИ МОДЕРНИЗАЦИИ}

В статье рассмотрены проблемы, связанные с подготовкой руководителя учреждения образования к адаптивного управления в условиях магистратуры. В частности приведены теоретические достижения по подготовке специалистов по управлению в науке. Отмечено, что возможности использования адаптивного подхода и механизмов совершенствования подготовки специалистов по управлению образованием в педагогической науке не исчерпаны. Раскрыто концептуальные идеи адаптивного управления в отечественном и зарубежном менеджменте и намечены значение такого управления для повышения качества подготовки руководителей образования. Указано, какие темы стоит изучать с адаптивного управления для совершенствования подготовки руководителя учебного заведения в условиях магистратуры. Предложена концепция кайдзен с японского менеджмента для модернизации подготовки специалистов по специальности 073 Менеджмент в условиях магистратуры. Определены новые задачи такой подготовки. Раскрыты принципы, которые внесут новые элементы в подготовку специалистов и показано модель компетентности будущих специалистов, которая может быть использована в образовательно-научной программе. Модель компетентности будущего руководителя образования по проблемам адаптивного управления разработана с дескрипторами в соответствии со спецификой адаптивного управления. 
Дальнейших исследований требует исследования проблем разработки критерии оценки компетентности магистров по использованию механизмов адаптивного управления, обоснование модели управленческой практики в дистанционном режиме и разработки тестовых заданий для проверки соответствующей компетентности.

Ключевые слова: адаптивное управление, подготовка руководителей, магистратура, модернизация, образовательно-научная программа, концепция кайдзен, модель компетентности.

\section{BODNAR OXANA,}

Doctor of Pedagogical Sciences, Associate

Professor of the Department of Pedagogy

and Education Management, Ternopil

Volodymyr Hnatiuk National Pedagogical

University, Ternopil, Ukraine.

\section{PREPARATION OF THE HEAD OF THE EDUCATIONAL INSTITUTION FOR ADAPTIVE MANAGEMENT IN THE CONDITIONS OF THE MAGISTRACY: CONCEPTUAL LINES OF MODERNIZATION}

The article considers the problems related to the preparation of the head of the educational institution for adaptive management in the conditions of magistracy. In particular, theoretical achievements in the training of management specialists in science are given. It was noted that the possibilities of using an adaptive approach and mechanisms for improving the preparation of education management specialists in pedagogical science have not been exhausted. The conceptual ideas of adaptive management in domestic and foreign management are revealed and the importance of such management is outlined to improve the quality of training of education managers. It is indicated what topics should be studied from adaptive management to improve the training of the head of the educational institution in the conditions of master's studies. The concept of Kaizen with Japanese management for modernization of preparation of specialists in the specialty 073 Management in the conditions of magistracy is proposed. New tasks for such preparation have been identified. Principles are disclosed that will introduce new elements into the training of specialists and show the model of competence of future specialists, which can be used in the educational and scientific program. The competency model of the future head of adaptive management education is developed with descriptors in accordance with the specifics of adaptive management.

Further research requires research into the problems of developing criteria for assessing the competence of masters in the use of adaptive management mechanisms, substantiating the model of management practice in remote mode and developing test tasks to test the relevant competence.

Key words: adaptive management, leadership training, master's degree, modernization, educational and scientific program, kaizen concept, competence model.

\footnotetext{
(C) Українська інженерно-педагогічна академія

(c) ГО «Школа адаптивного управління сочіально-педагогічними системами»

(C) Боднар 0 .
} 